\title{
琵琶湖流域既往最大洪水の復元による淀川水系 の治水計画の検討
}

The examination of the present flood control plan for the Yodo River System based on simulated flood damages by the recurrence of the largest recorded flood in Lake Biwa basin

\author{
石河康久 1 - 西川真介 2 -中西宣敬 3 - 安田全男 4 - 井町建夫 5 - 田中洋一 6 - 定道成美 7 \\ Yasuhisa ISHIKAWA, Shinsuke NISHIKAWA, Noritaka NAKANISHI, Masao YASUDA, Tatsuo IMACHI, \\ Yoichi TANAKA and Shigemi SADAMICHI
}

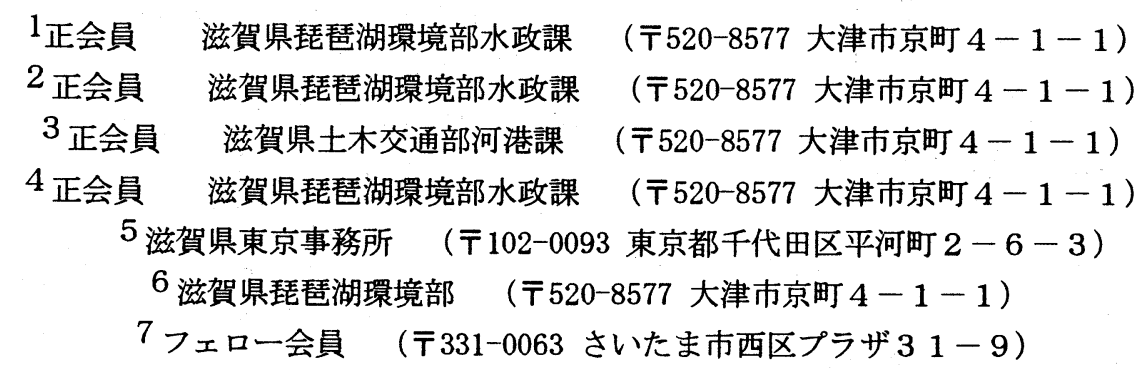

People living at Lake Biwa shoreline areas have suffered from inundation damages from the ancient time, they strongly desire to relieve themselves from these damages. The largest recorded flood in Lake Biwa basin after Meiji Restoration occurred in 1896 , but it occurred long time ago so that little hydrological and hydraulic data such as rainfall data, discharge data of the rivers which are basic information for preparing a flood control plan are left. Therefore we can't take this flood into consideration when we make the flood control plan for Lake Biwa basin. Based on the importance of the analysis of the largest recorded flood, we tried to collect as much data as possible about this flood and simulate this flood correctly based on collected data. And we also analyzed the damage by this flood. Due to the results of the analysis, if this flood occurred now, the water level of Lake Biwa would be higher than the present design flood level even if Setagawa Barrage, which was constructed at the outlet of Lake Biwa, were totally opened. On the other hand, the precipitation in the Kizu and Katsura River basins would be not very large, so the present river-related facilities would be enough for the prevention of the flood damage even if Setagawa Barrage were totally opened. But for the Uji River basin, it is clear that further counter measures for this flood must be taken because the discharge in the river would exceed the actual capacity of flow.

Key Words : The largest recorded flood, flood control plan, Lake Biwa, Setagawa Barrage, Yodo River, Uji River, Kizu River, Katsura River

\section{1. はじめに}

治水計画を立案する際には，まず，目標とする洪水を 定める必要がある. 既往洪水の流量あるいは降雨資料を 収集し，これらを統計処理し，所定の安全度に対応する 計画洪水が定められる1)。目標とする洪水は，河川の重 要度に応じて上下流, 本支川でバランスを考慮して定め られるが，既往最大洪水はその基本となるものである. もちろん, 統計的な手法をとる場合においても解析の信 頼性の観点から最大洪水は不可欠なデータであることは 言うまでもない.

一方，琵琶湖浻岸は古くから浸水被害に苦しみ，この 解消が現在も当地域住民の悲願となっている. 琵琶湖流 域の近代以降の既往最大洪水は明治 29 年(1896)に生起
しているが，治水計画検討の基本となる雨量，流量等の 水理・水文資料が乏しく十分検討できず，淀川改修計画 も明治 37 年以後の資料に基づき樹立されているため, 治水計画立案の対象からはずされている22.

琵琶湖淀川流域の洪水には，全流域の約 5 割を占める 琵琶湖流域からの流入が琵琶湖に貯留され，そこからの 流出河川は瀬田川のみであり，その流量が瀬田川洗哐で 人為的に管理されているという特殊性が存する. このこ とが, 長年にわたる上下流の対立の原因となり，流域の 治水面の根元的課題となっている.

この研究では, 既往最大洪水を分析することの重要性 と琵琶湖淀川流域の洪水の特性に鑑み, 明治 29 年の洪 水時の水理・水文資料を広く収集し，これらに基ついて この洪水の復元を試みる. また, この既往最大洪水が再 


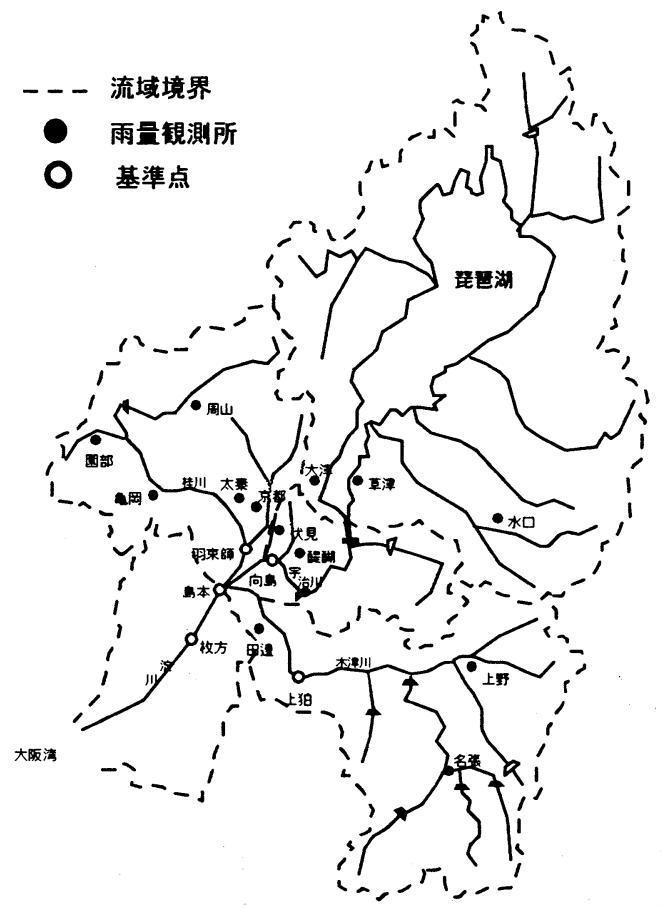

図一1 淀川・琵琶湖流域図

来した場合のシミュレーションを行い，今後とるべき治 水対策について考察する.

通常, 目標洪水算出には, 比較的確率処理がしやすく, また, 資料が得やすい降雨に着目して解析を行い, 計画 降雨を定め, これから流出解析によりハイドログラフに 換算する手法が採られることが多いが1)，この研究では， 流出解析等様々なパラメータを含み，ブラックボックス となる手法はあえて避け，一般に公開されたデータのみ を用い，算出過程がわかりやすい手法を採っている.

\section{2. 琵琶湖流域既往最大洪水の復元}

\section{（1）琵琶湖流域における既往最大洪水}

図一1に示すように，淀川は京都府八幡市付近におい て宇治川，木津川および桂川の三川が合流し，大阪平野 を西南に流下する．淀川流域の最大の特徽は宇治川上流 の琵琶湖の存在にある. 三川合流から上流の流域面積は 約 $7,050 \mathrm{~km}^{2}$ であるが，そのうち琵琶湖の流域面積は約 $3,848 \mathrm{~km}^{2}$ と 5 割以上を占めている．淀川の治水計画では 琵琶湖の巨大な貯水容量を利用し，流域からの洪水流出 をほぼ全面的に貯留することとしている．琵琶湖から宇 治川への出口には洗堰があり, 琵琶湖の水位はここでコ ントロールされている．堰を閉めることは宇治川および 淀川の流量を減じ，洪水の危険を軽減させるが，逆に玨 琶湖水位の上昇をもたらし, 琵琶湖沿岸の浸水の危険を 増大させる. また, その容量の大きさのために, 洪水後 の琵琶湖の水位低下には長時間を要する.このことは, 下流において洪水の危険が去った後, 琵琶湖沿岸は逆に 最も危険な状態にさらされ，次の洪水が来たときは，計 り知れない災害をもたらすことを意味する. そのため, 速やかな琵琶湖水位の低下は，淀川水系の重要な治水対 策として明治以来取り上げられて来ている.
表一 1 琵琶湖沿岸の主な浸水被害

\begin{tabular}{|c|c|c|c|c|c|c|}
\hline \multirow{2}{*}{$\begin{array}{c}\text { 洪水生起 } \\
\text { 年月 }\end{array}$} & \multirow{2}{*}{$\begin{array}{c}\text { 降雨日数 } \\
\text { (日) }\end{array}$} & \multirow{2}{*}{ 洗堰操作 } & \multicolumn{2}{|c|}{ 実續ピーク水位 } & \multirow{2}{*}{$\begin{array}{c}\text { 浸水時間 } \\
\text { （日） }\end{array}$} & \multirow{2}{*}{$\begin{array}{c}\text { 浸水面皘 } \\
\text { (ha) }\end{array}$} \\
\hline & & & 鳥居川 & 彦根 & & \\
\hline M29年9月 & 10 & 堰なし & 3.76 & - & 238 & 約 16,500 \\
\hline T6年10月 & 3 & 全閉操作 & 1.43 & 1.32 & 68 & 約 6,200 \\
\hline S28年9月 & 3 & 全閉操作 & 1.00 & 1.18 & 17 & 約 4,000 \\
\hline S36年6月 & 6 & 全閉操作 & 1.10 & 1.30 & 24 & 約 4,700 \\
\hline S47年7月 & 5 & 全閒操作 & 0.92 & 1.26 & 12 & 約 3,400 \\
\hline H7年5月 & 7 & 放流制限 & 0.80 & 0.93 & 11 & 約750 \\
\hline
\end{tabular}

注）出典 : 近畿地方整備局琵琶湖河川事務所「天ヶ瀬ダム再開 発計画についての説明資料」 ${ }^{4)}$

$※$ 平成 7 年 5 月洪水の彦根水位は, 琵琶湖平均水位 ※平成 4 年 4 月に鳥居川及び彦根水位観測所の零点高を変更 ※大正 6 年 10 月及ひ昭和 28 年 9 月の洪水では結果的に全閉ま でには至らなかった。 ※浸水時間は 29 年 9 月は水位が $+1.83 \mathrm{~m}$ 以上の日数であり，その 他は水位が +0.5 m以上の日数

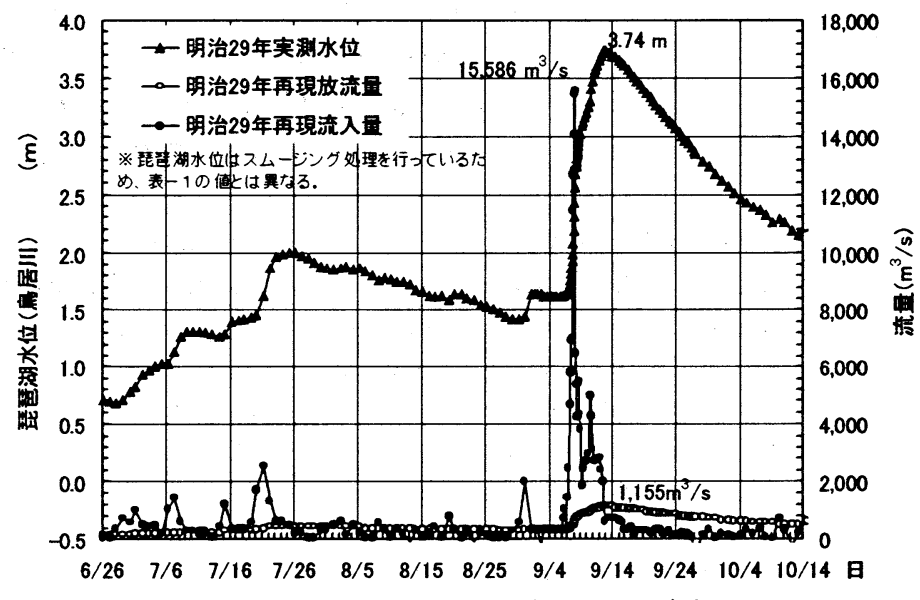

図一２明治29年の琵琶湖水位および流量

ここでは琵琶湖の最高水位をもたらした洪水を復元す るが，併せてその時の木津川および桂川の洪水も復元し， 宇治川および淀川本川流量を含めた考察を行う. なお， 淀川本川の既往最大洪水は，今回取り上げる琵琶湖流域 の既往最大洪水とは異なっており，当然のことながら別 途, 対応がとられている゙3.

表一 1 に記録の残された明治以降の主な琵琶湖におけ る洪水を, 図一 2 に明治 29 年洪水の琵癸湖水位を示す ${ }^{5), 6)}$. もっとも大きな水位上昇は明治 29 年 9 月の +3.76 $\mathrm{m}$ (BSL) で, 浸水は 8 ヶ月近くに及んでいる. これは, 7 月の出水により琵琶湖水位が上昇したままに 9 月の洪 水を迎えた結果であり，前述した洪水後の琵琶湖水位の 速やかな低下が必要であることを如実に物語っている.

（BSLとは琵琶湖水位のことで，BSL 0mは標高84. 371mに 相当する. 以下，特に断らない限り琵琶湖水位は全て BSLで表記する．）なお，実測水位には，セイシュ等に 起因する数 $\mathrm{cm}$ から数 $10 \mathrm{~cm}$ 程度の振動が含まれており，こ のままでは琵琶湖流入量逆算等の解析作業に不都合が生 
じる. このため, 図一 2 のような水位のスムージング処 理を行っている. また，以降の検討はこの水位を用いて 行う.

\section{（2）洪水復元の基本的な考え方}

\section{(a) 基礎データ}

明治 29 年の洪水に関するデータは，今回初めて集め た結果, 以下のとおりである.

(1)流域雨量

津地方気象台管内 14 力所, 彦根地方気象台管内 12 力所および京都地方気象台管内 19 力所の雨量観測地点 が存在した. これらのうち京都と彦根地点は 4 時間雨量 の記録があるが, 他は全て日雨量のみの記録である.

(2)流量

今回の検討の対象とする淀川各支川の当時の水位観測 地点は, 向島 (宇治川)，上狛（木津川）, 羽束師（桂 川）である. 明治 29 年洪水は断続した雨によるもので あるため数回の流量ピークが存在するが，これらの地点 ではその一部のピークについて，水位，流量（宇治川を 除く）お およびその発現時刻の記録が残されている7).

(3)琵琶湖水位

琵琶湖水位は，毎正時のデータが存在する.

(4)京都 4 時間雨量データ

明治 29 年洪水時の京都の 4 時間雨量データを図一 3 に示す. 図からわかるようにこの洪水は，数回のピーク を持つ断続的な降雨から生じている.この図から，明治 29 年洪水は，図中太破線に挟まれた $8 / 30 ， 9 / 6 \sim 7$, $9 / 8 ， 9 / 9 ， 9 / 10 ， 9 / 11$ の 6 洪水に分けられるものと判断 した.

\section{(b) 洪水復元の基本的な考え方}

洪水の復元の最終目標は，ハイドログラフである。こ こでは，数回生じているピーク流量毎に他の既往洪水の ハイドログラフを後述の方法により拡大あるいは縮小し て当てはめることにより，上記 6 洪水のハイドログラフ をそれぞれ復元し，重ね合わせることにより全体のハ ドログラフを復元することとした.

この復元を宇治川，木津川，桂川の各水位観測地点に おいて行いこれれらからさらに淀川本川枚方地点のハイ ドログラフを復元する. ただし，宇治川については，琵 琶湖からの流出とそれ以外の残流域加らの流出に分けて 算出を行っている. すなわち, 琵琶湖流出量については 琵琶湖水位から算出し, 残流域からの流出量については 前述のあてはめの方法によった。

\section{（3）各洪水のピーク流量の算出}

各流域の各洪水のうち実測ピーク流量が存在しない場 合は，以下の方法でピーク流量を定めた.

\section{（a）流域平均雨量の算出}

各支川の流域の主な雨量観測地点から流域平均雨量を 算出する. 宇治川では大津, 草津, 水口, 上野, 田邊,
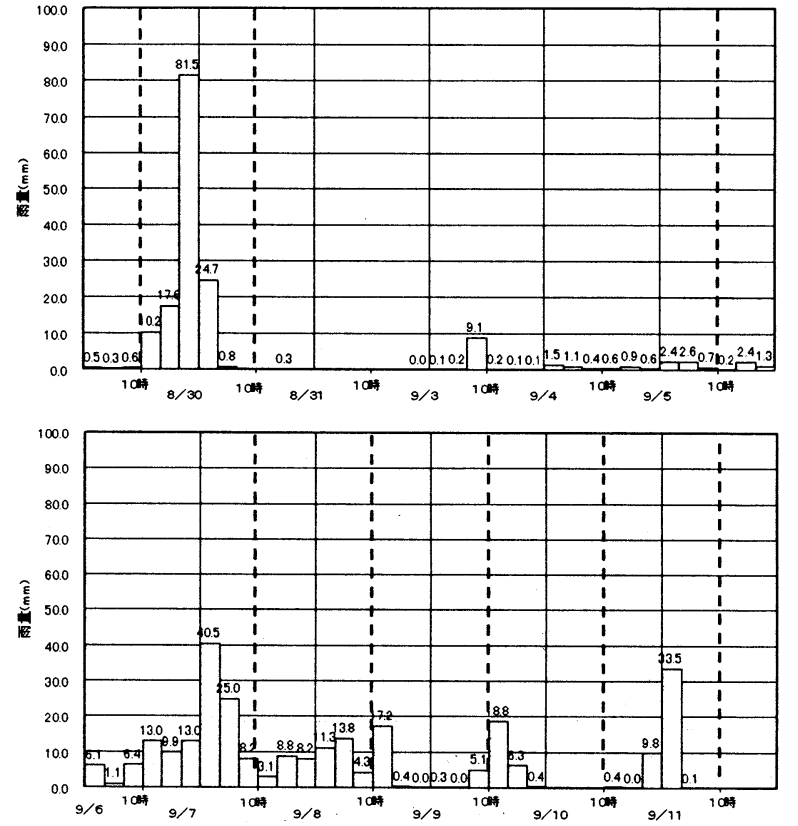

図一3 明治2 9年洪水時の京都雨量

伏見およひ醍醐の 7 地点，木津川では名張および上野の 2 地点, 桂川では太秦, 亀岡, 園部および周山の 4 地点 の平均とした. 図一 1 に算出に用いた観測地点を示す。 なお，大津と草津，伏見と醍䠒については観測地点が接 近しているので, あらかじめ 2 地点での平均操作を行っ た後に, 改めてこの平均值を含めて他の地点との平均を 取っている，宇治川は，流域内の観測地点が限られてい たため，上流域を流域外の水口と上野で代表させ，下流 域は大津と草津の平均, 伏見と醍醐の平均および田邊で 代表させ，計5つの代表値から平均することとした.

得られる流域平均雨量は日雨量であるが，幸いにも明 治 29 年洪水は前述したように日単位の洪水に分割でき ることから，これらを洪水毎の流域平均雨量と読み替え ることができる. 9/6〜7洪水は 2 日間の合計雨量を用い る.

次に, 求めた流域平均雨量から損失雨量を差し引いて 有効雨量を求める. 損失雨量は「淀川・大和川の洪水資 料（その2）」(近畿地方建設局) ${ }^{8)}$ に示された各流域 における值をそのまま用いた. 各流域の損失雨量は, 宇 治川で90mm，木津川で62 $\mathrm{mm}$ ，桂川で46mmである．なお， 図ー3に示すように $9 / 8$ から $9 / 11$ の間は連続した降雨な ので損失雨量は見込んでいない.

\section{(b) 各流域における有効雨量とピーク流量の関係}

次に前述の方法により得られた有効雨量からピーク流 量を求めるために, 各流域における既往洪水のピーク流 量と有効雨量のデータ ${ }^{8)}$ 整理し，両者の相関式を曲線 近似により求めた，一般に, 洪水のハイドログラフは, 洪水流量が大きくなるほどピークが鋭く立ち, 相対的に 大きなピーク流量となる傾向があることを考慮し，相関 式は多項式 (二次式) あるいは累乗式とした. また, 有 効雨量とピーク流量の関係なので原則として原点を通る 


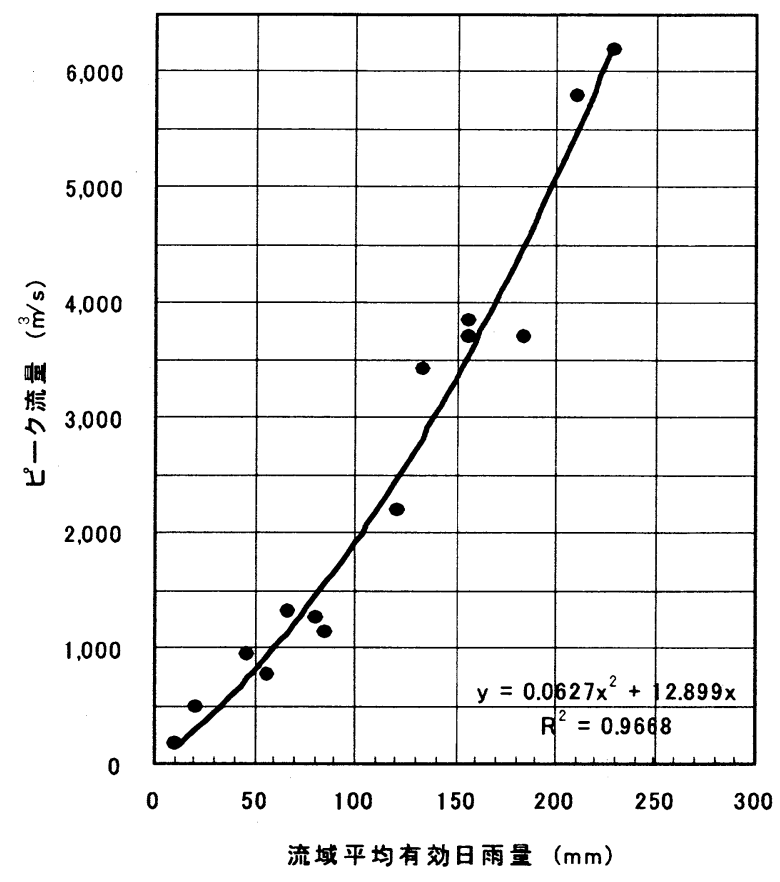

図ー4 木津川における有効雨量とピーク流量の関係

曲線となると仮定し，これらの中で最も大きい相関係数 を示す近似曲線を採用した. 図一 4 に木津川の例を示す. 各流域とも二次式がもっとも相関係数が大きく，全ての 流域において0.95以上となっており，推定に十分な精度 は確保できていると考えられる. ただし，桂川は二次の 係数はほぼ 0 ，すなわち一次式と見なせた。 これらの式 を用いて, 有効雨量からピーク流量を求めることとした.

\section{（4）各流域の洪水波形の特徵}

図一 5 に，木津川における既往洪水をピーク流量等に よりパターン分け（大洪水，中洪水，小洪水）したもの を示す．これらを見ると中洪水以上では，ほぼ全ての洪 水波形が相似形をとることがわかる. 中洪水のうちひと つおよび小洪水では明らかに波形が異なるものがあるが, これらは雨量に明確なピークが存在しない長雨タイプの ものと二つの雨量ピークを持つ洪水であった. この現象 は宇治川および桂川についても同様であった.

一方，図一 3 に示寸雨量を $8 / 30 ， 9 / 6 \sim 7 ， 9 / 8 ， 9 / 9$, 9/10，9/11の 6 洪水毎に分けて見ると，9/8を除いては 明確なピークをひとつ持つ雨量パターンであることがわ かる.

したがって, 長雨タイプのものと二つの雨量ピークを 持つ洪水を除く同程度のピーク流量を持つ既往洪水の八 イドログラフを，ピーク流量が一致するように拡大ある いは縮小してやれば明治 29 年の各洪水の復元が可能で あることがわかる. ただし，9/8については同様の雨量 パターンを持つ洪水を慎重に選択する必要がある.

こうした手順により 6 洪水毎にハイドログラフを選択 したら, 次にこれらを時間軸に当てはめ, 重ね合わせを 行う。この際にピーク発現時刻をどこに合わせるかが問
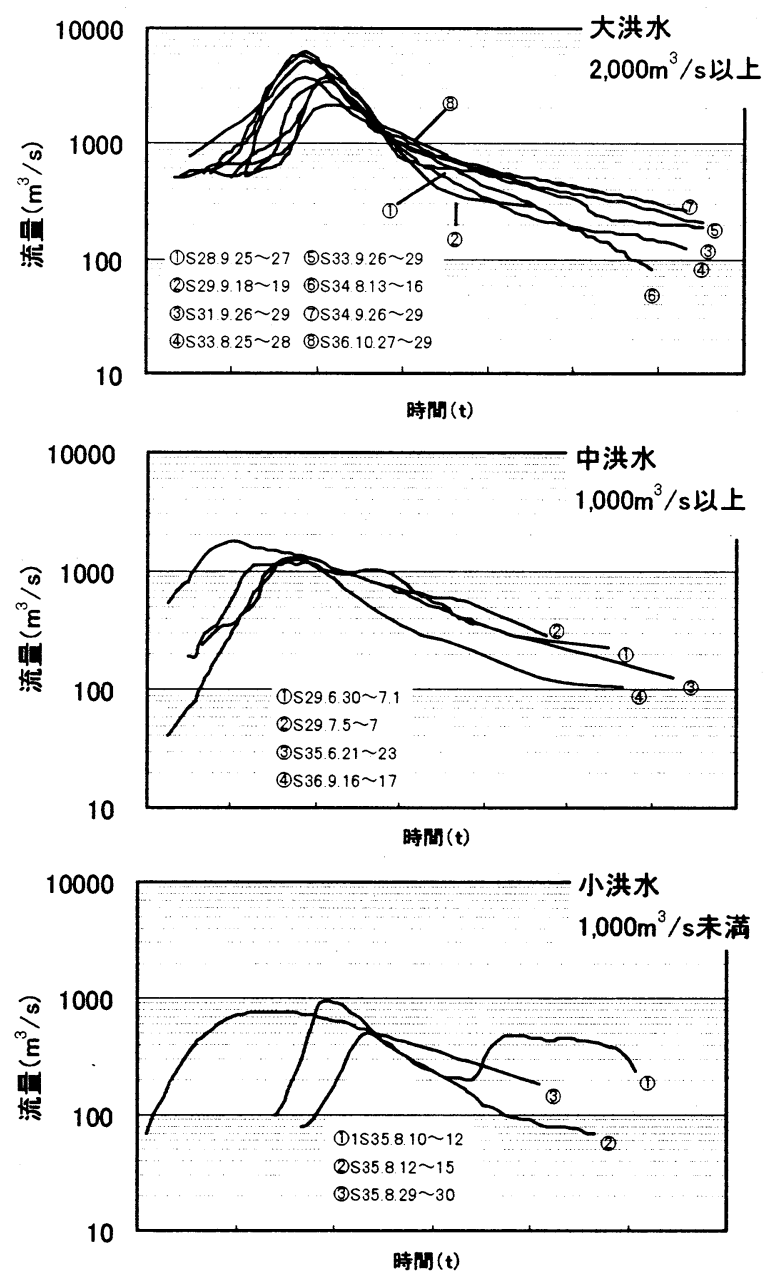

図一5 木津川の洪水パターン

題となる.ここでは既往洪水における雨量ピークの終了 時間と流量ピークの発現時間の差を整理し, 流域每に平 均的な遅れ時間, 具体的には宇治川では 3 時間, 木津川 では 4 時間，桂川では 9 時間の遅れ時間を設定した.

\section{(5) 琵琶湖放流量の算出方法}

前述のとおり, 宇治川の流量は琵琶湖からの流出とそ れ以外の残流域からの流出に分けて算出を行っている. ここでは琵琶湖流出量の求め方について説明する. 琵琶 湖水位の時間データ（図-2）が存在するので, これか ら流出量を算定する. 明治 29 年当時には, 洗堰は存在 せず，琵琶湖の水は人為的にコントロールされることな く，鳥居川を経て宇治川へと流出していた，金森りによ れば，鳥居川水位に対する流出量は次式で与えられる.

$$
Q=52.73(h+0.94)^{2}
$$

この式を用いて実績水位から琵琶湖流出量を算定する. 図一 2 中の琵琶湖流出量は実測水位加式(1)を用いて 算定した值である。流出量は最高水位 $3.76 \mathrm{~m}$ 時に $1,155 \mathrm{~m}^{3} / \mathrm{s}$ 記録している.

\section{（6）既往最大洪水の復元}

最後に, 流域毎に求められたハイドログラフを重ね合 わせることにより淀川本川のハイドログラフを求める. 


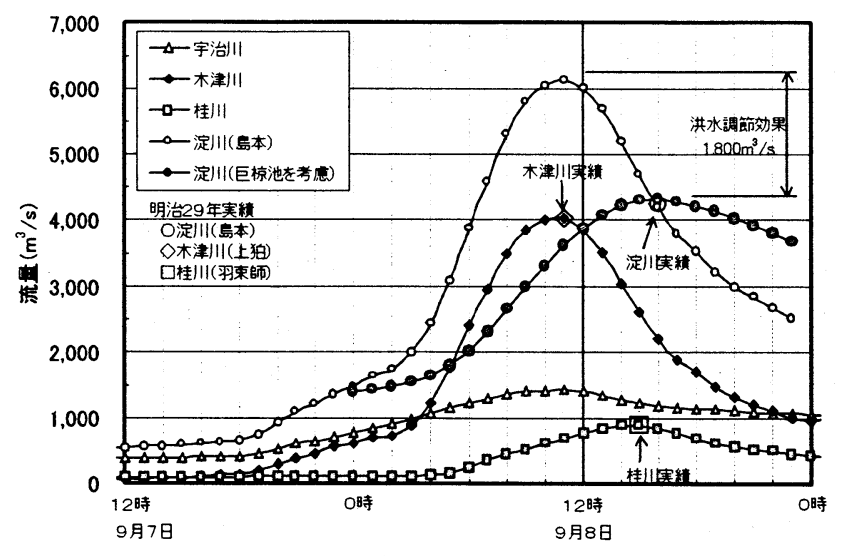

図-6 明治 29 年洪水の再現

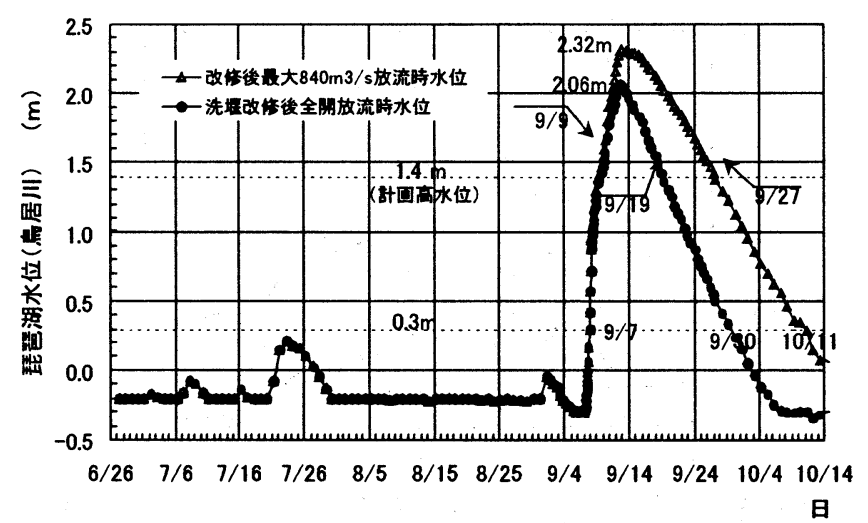

図一7 洗堰整備後の明治 29 年洪水時琵琶湖水位

-0.08mまで下がり，洪水時には堰を全閉して流出を止 めるが，それによる湖水位上昇は $20 \mathrm{~cm}$ 程度とされていた。

その後, 大正 6 年, 昭和 28 年をはじめ度重なる洪水 に見舞われ，治水計画が見直された。. 昭和36年に現在の 瀬田川洗堰が完成し，現在に至っている.

\section{（2）琵琶湖水位}

明治 29 年洪水再来時に, 現洗堰を全開した場合の琵 琶湖水位のシミュレーション結果を図ー 7 に示す. 瀬田 川浚渫や洗堰等の整備により琵琶湖からの放流能力が増 強された結果，琵琶湖の水位上昇は明治29年当時の3.76 $\mathrm{m}$ (図一-2) から $1.7 \mathrm{~m}$ 下がり，2.06mとなるが,これ は現在の琵琶湖の計画高水位 $1.4 \mathrm{~m}$ をはるかに上回って いる.

しかも，10日間に渡って $1.4 \mathrm{~m}$ 超えており, 最高水 位時には湖岸堤の天端高さである $2.6 \mathrm{~m} に$ 迫っている. 明治 29 年の洪水時には半振幅 $50 \mathrm{~cm}$ 程度のセイシュが観 測されており，台風時には風波が生じることを考えると， 湖岸堤に余裕はなく，越水が発生し，その対応が必要で あると考えられる。 また，琵琶湖水位が $0.3 \mathrm{~m}$ 以上とな ると内水被害が生じるおそれがあるとされているが，23 日に渡ってこの水位を超えており，この対策が不可欠で ある。

また, 琵琶湖下流の宇治川は, $1,500 \mathrm{~m}^{3} / \mathrm{s}$ をて柾通能 力を増大させる計画となっているが，現在その疎通能力 は実現されていない，このため図一 7 中には，琵琶湖か らの放流量を $840 \mathrm{~m}^{3} / \mathrm{s} に$ 抑えた場合の水位を併せて示し てある. 図からわかるように，全開時には計画高水位を 超える日数は10日であったものが， $840 \mathrm{~m}^{3} / \mathrm{s}$ 制限を行う と18日にもなり, 最高水位もさらに $20 \mathrm{~cm}$ 以上も上昇し, $2.32 \mathrm{~m}$ に達する. 琵琶湖水位が $0.3 \mathrm{~m}$ 在超える日数も 1 ヶ 月以上に及ぶことがわかる.

\section{（3）淀川本川流量}

現在の河川整備状況において琵琶湖流域の既往最大洪 水が再来した場合の淀川本川および支川のシミュレー ション結果を図ー8に示す. 図一 6 と同様に全て本川基 淮点（枚方地点）の時間に合わせてある. なお，洗堰は 


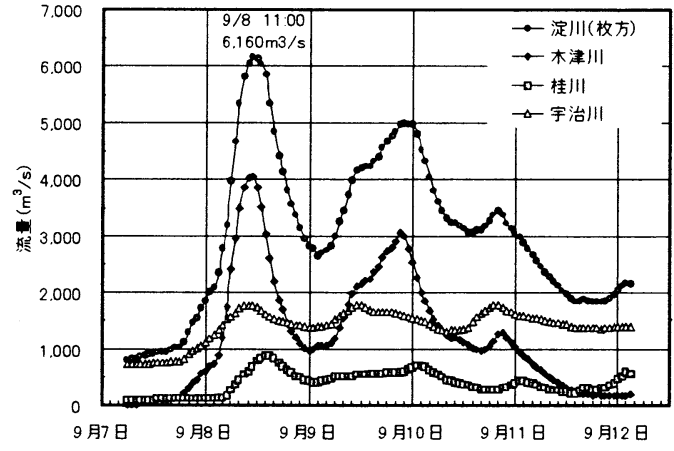

図ー8 現計画整備後における明治 29 年洪水の再現

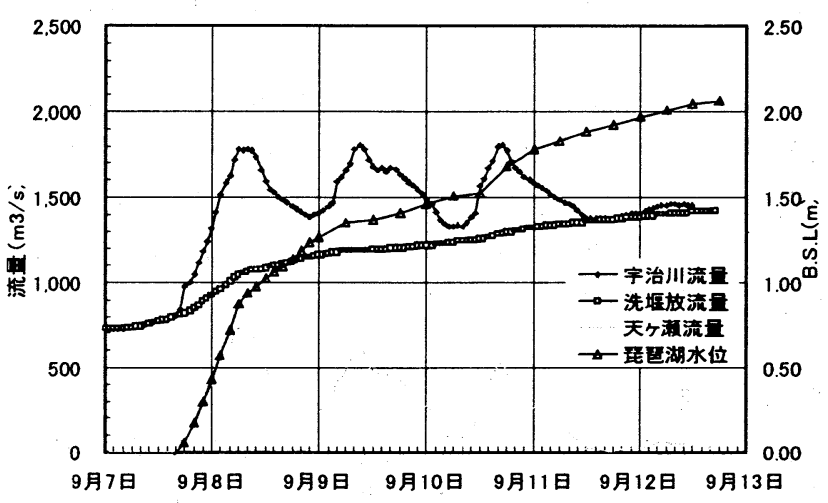

図一9 洗堰全開時の明治 29 年洪水時宇治川流量

現計画整備後とし，全開で放流するものとした.

計画的に河川整備が進められた結果，現在の淀川本川 （枚方地点）の㻋通能力は，ほぼ $9,400 \mathrm{~m}^{3} / \mathrm{s}$ 程度あると されている. この洪水は琵琶湖流域には大きな雨量をも たらしたものの，木津川および桂川流域の雨量は非常に 大きくはなかったため，洗堰を全開放流しても，図一8 から明らかなように，淀川本川については $6,160 \mathrm{~m}^{3} / \mathrm{s}$ と なり，現行の河川施設の踈通能力の範囲内であることか ら，全閉には至らない。しかし，宇治川は疎通能力 $1,500 \mathrm{~m}^{3} / \mathrm{s}$ 以上の洪水となる. これについては次節で考 察する.

\section{（4）宇治川流量}

図一9に洗堰全開時の洗堰放流量，宇治川流量および 琵琶湖残流域流量（図中天ヶ瀬流量）を示寸．図から明 らかなように，宇治川流量は計画目標とされている $1,500 \mathrm{~m}^{3} / \mathrm{s}$ まで疎通能力が増大されても明治 29 年洪水 を安全に流下させることができない.

しかし，これを回避するために，琵琶湖水位が急上昇 しつつある中で洗堰を全閉して放流量を減少させること は，明治 29 年の未曾有の洪水の恐怖に戦いている県民 にとっては現実には不可能である.ここでは，琵琶湖残 流域からの流出量を貯留する施設による対応を想定し， その施設規模を概算してみる. 図中の宇治川流量が $1500 \mathrm{~m}^{3}$ /sを超える部分を全て貯留することができる施設 であればよく，この量を計算すると約 2,600 万 $^{3}$ となる. 宇治川流域の地形や現在の土地利用状況を考えると, こ
の規模の貯留施設としてはダムが考えられる.

\section{4. おわりに}

明治 29 年に生じた琵琶湖流域の既往最大洪水につい て，公開された資料からの復元を試みた．得られた復元 結果は，残されていた実績データともほぼ一致しており， 治水計画検討に十分な精度を有していると考えられる.

またこれを用いて，この洪水が現在再来した場合の現 在の河川施設等を検証した結果, 以下のことが判明した.

- 琵琶湖の出口である洗堰を全開としても, 琵琶湖水 位は現在の計画高水位を $66 \mathrm{~cm}$ 超えるため, 内水被 害への対応はもちろんのこと, 堤防越流の対応につ いて検討する必要がある.

- 淀川本川については, 木津川および桂川流域の雨量 は非常に大きくはなかったため, 洗堰を全開として も現行の河川施設の疎通能力の範囲内である.

・宇治川については現行の計画流下能力を超えるため, ピーク流量をカットするための新たな貯留施設が必 要であると考える.

今回の検討により，琵琶湖・淀川水系における治水計 画上の課題が明らかになった. 今後は, 琵琶湖淀川流域 に特有の洗堰全閉操作の解消を目指して検討を進めてい きたい.

旧南郷洗堰の設置から100年が経過した今，洗堰の全 閉を前提とする，つまり上下流の対立を前提とする治水 計画が根本的に転換され，長年にわたる上下流対立の解 消に向かうことを願うところである.

本論文の作成にあたっては, 谷本光司氏, 桜井力氏, 㴊上吾郎氏，藤井幹大氏に多大のご協力を賜りました. ここに記して謝意を表します。

\section{参考文献}

1）国土交通省河川局 : 国土交通省河川砂防基準計画編，pp. 123,2004

2）近畿地方建設局 : 淀川百年史, pp. 1451-1452, pp. 1074-1075, 1974

3）建設省河川局 : 淀川水系工事実施基本計画, pp. 1-20, 1994

4）近畿地方整備局琵琶湖可川事務所「天ケ瀬ダム再開発計画に ついての説明資料」，2004

5) 近畿地方建設局淀川工事事務所：淀川治水史（锟琶湖関倸）, pp. 63-70, 1969

6) 近畿地方建設局琵琶湖工事事務所 : 琵琶湖水文資料水位 - 流 量吕（1874-1975）水位（鳥居川）集計リスト， 1977

7）淀川大和川洪水連絡会 : 淀川・大和川の洪水資料（その 一) , pp. 1-428, 1960

8）近畿地方建設局：淀川 - 大和川の洪水資料（その二）, pp. 1-138, 1964

9）金森釷太朗：瀬田川に於ける流量曲線の時間的変遷，土木 学会誌，第2巻, 第1 号, pp93-189, 1916

(2004.9. 30 受付) 